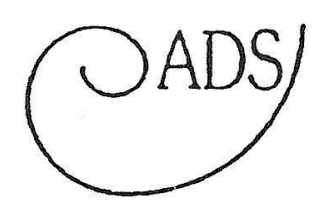

Andragoško društvo Slovenije Slovene Adult Education Association Ljubljana, Šmartinska 134 a, Slovenija tel.: 061/446-482

\title{
LETNI POSVET ANDRAGOŠKEGA DRUŠTVA SLOVENIJE
}

L nije je potekal 12. in 13. maja v Novi Gorici. Udeležilo se ga je 70 od 410 članov društva. Strokovni del srečanja je bil tokrat $\mathrm{v}$ celoti namenjen pripravam na Unescovo konferenco o izobraževanju odraslih, ki jo organizirajo vsakih 12 let. Tako bodo slovenski andragogi na konferenci, ki bo julija v Hamburgu, svetovni javnosti predstavili nove načine izobraževanja odraslih $\mathrm{v}$ Sloveniji, študijske krožke, učenje v lokalnih skupnostih. Veliko pozornosti so namenili tudi izboljšanju razmer in kakovosti izobraževanja odraslih, pa tudi uvajanju nove informacijske tehnologije za kvalitetno računalniško podprto izobraževanje odraslih.

$\mathrm{V}$ okviru dvodnevnega posveta je ADS pripravilo tudi skupščino, na kateri so za novo predsednico društva izvolili Melito Cimerman, direktorico Andragoškega zavoda $\mathrm{Ma}$ ribor. Nova predsednica je nasledila dosedanjo predsednico Jasno Dominko - Baloh.

Na skupščini so sprejeli tudi programske usmeritve ADS za prihodnje obdobje.

\section{PREDLOG PROGRAMSKIH USMERITEV ADS ZA PRIHODNJE OBDOBJE}

1. Uveljavljanje učenja in izobraževanja odraslih kot dejavnosti, ki ima strateški pomen za razvoj posameznika in družbe. Pri tem je treba zlasti:

- vplivati na oblikovanje takih razmer, ki bodo pozitivno vplivale na razvoj učenja in izobraževanja odraslih (alternativne poti in načini izobraževanja, samostojno učenje, ugotav- ljanje in potrjevanje znanja ipd.);

- razvijati in uveljavljati andragoško stroko in vse vidike njenega delovanja, ki jih je treba udejanjati za uspešen razvoj učenja in izobraževanja odraslih (izobraževanje andragoških in drugih strokovnih delavcev in delavk v izobraževanju odraslih, raziskovalnorazvojno delo, svetovalno delo v izobraževanju odraslih, razvoj novih oblik in metod dela ipd.).

2. Skrb za strokovni razvoj andragogov in andragoških delavcev. Pri tem je pomembno zlasti informiranje, seznanjanje z novostmi in razvojem stroke, povezovanje in stiki med članstvom, povezovanje $\mathrm{z}$ drugimi strokovnjaki v Sloveniji in $\mathrm{v}$ tujini, društvi s sorodnimi nalogami (kadrovska društva, društva pedagogov, sociologov) doma in $v$ tujini.

3. Aktivno vključevanje $\mathrm{v}$ prenovo programov izobraževanja odraslih in pripravo nacionalnega programa izobraževanja odraslih in letnih načrtov.

4. Pomoč članstvu pri reševanju strokovnih vprašanj, ki jih zanimajo.

5. Aktivno spremljanje in analiziranje zakonodaje in pravnih predpisov za izobraževanje odraslih, spodbujanje k spremembam in opozarjanje na probleme $\mathrm{v}$ praksi.

6. Nadaljevanje članstva v Evropskem društvu za izobraževanje odraslih (EAEA - European Association of Adult Educators) in so-
Melita Cimerman, nova predsednica $A D S$ 
delovanje z njimi pri pripravi projektov in akcij.

7. Kandidiranje za projekte, ki jih razpisujejo mednarodne organizacije (Evropska skupnost ipd.), in aktivno sodelovanje v projektih drugih društev.

Navedene temeljne smeri delovanja bo mogoče izvesti le z:

- aktivnostjo organov ADS na republiški rav$\mathrm{ni}$ in

- aktivnostjo podružnic in sekcij.

$\mathrm{V}$ preteklih obdobjih se je pokazalo, da:

- tam, kjer ni bilo aktivnega in zavzetega vodstva, ni bilo niti aktivnosti (programov, akcij, pobud ipd.);

- je treba za aktivno in kontinuirano delo ustvariti določene objektivne delovne razmere (prostor, povezanost $\mathrm{z}$ matično institucijo, profesionalizacija določenih funkcij), to smo dobili z ustanovitvijo Andragoškega centra in od tod je treba izhajati;

- da se mora ADS pri svojem delu povezovati $\mathrm{z}$ drugimi strokami in sorodnimi organizaci- jami, če hoče zadovoljevati različne potrebe andragogov in andragoških delavcev.

Iz navedenega izhajajo naslednje usmeritve glede organiziranosti delovanja ADS:

- revitalizirati delovanje ADS, okrepiti delovanje podružnic, ki člane društva povezujejo $\mathrm{v}$ regiji, in tam, kjer lahko člani zadovoljujejo svoje potrebe;

- poiskati čim več možnosti skupnega nastopanja in organiziranja dejavnosti in prireditev društva;

- organizirati vsakoletna letna srečanja andragogov in andragoških delavcev, ki naj jih skupaj z podružnicami izvaja ADS, in jih, tako kot doslej, povezovati z občnimi zbori, ker je to priožnost za povezovanje s članstvom in letno preverjanje, prilagajanje in dopolnjevanje programskih usmeritev,

- nameniti več pozornosti pridobivanju novega članstva in urejanju obveznosti članov, vsako leto analizirati število članov, plačevanje članarine in o tem poročati izvršnemu odboru in na občnih zborih.

Pripravili: Ema Perme in Daniela Brečko 